\title{
CF3I Gas Mixtures: Breakdown Characteristics and Potential for Electrical Insulation
}

DOI:

10.1109/TPWRD.2016.2524676

\section{Document Version}

Accepted author manuscript

Link to publication record in Manchester Research Explorer

\section{Citation for published version (APA):}

Chen, L., Widger, P., Kamarudin, M. S., Griffiths, H., \& Haddad, A. (2017). CF3I Gas Mixtures: Breakdown Characteristics and Potential for Electrical Insulation. IEEE Transactions on Power Delivery, 32(2), 1089-1097. https://doi.org/10.1109/TPWRD.2016.2524676

\section{Published in:}

IEEE Transactions on Power Delivery

\section{Citing this paper}

Please note that where the full-text provided on Manchester Research Explorer is the Author Accepted Manuscript or Proof version this may differ from the final Published version. If citing, it is advised that you check and use the publisher's definitive version.

\section{General rights}

Copyright and moral rights for the publications made accessible in the Research Explorer are retained by the authors and/or other copyright owners and it is a condition of accessing publications that users recognise and abide by the legal requirements associated with these rights.

\section{Takedown policy}

If you believe that this document breaches copyright please refer to the University of Manchester's Takedown Procedures [http://man.ac.uk/04Y6Bo] or contact uml.scholarlycommunications@manchester.ac.uk providing relevant details, so we can investigate your claim.

\section{OPEN ACCESS}




\title{
$\mathrm{CF}_{3}$ I Gas Mixtures: Breakdown Characteristics and Potential for Electrical Insulation
}

\author{
Lujia Chen, Member, IEEE, Phillip Widger, Mohammad Saufi Kamarudin, Huw Griffiths, Member, IEEE, \\ and A. Haddad, Member, IEEE
}

\begin{abstract}
SF}_{6}$ is a potent greenhouse gas, and there has been research into more environmental friendly alternative gases with the aim of replacing the use of $\mathrm{SF}_{6}$ gas in high-voltage equipment. So far, the research into alternative gases has shown that $\mathrm{CF}_{3} \mathrm{I}$ gas mixtures have promising dielectric properties comparable to those of $\mathrm{SF}_{6}$. This paper provides an overview of research into $\mathrm{CF}_{3}$ I gas and its mixtures, and gives an insight into its key properties. These include laboratory tests on the gas mixtures and initial applications to electrical power equipment. The insulation capability makes $\mathrm{CF}_{3} \mathrm{I}$ a feasible alternative to $\mathrm{SF}_{6}$ as an insulation medium where arc quenching is not required. On the other hand, iodine deposition after electrical discharge means $\mathrm{CF}_{3} \mathrm{I}$ may not be a suitable arc quenching gas for switchgear applications that require high current interruption unless a solution is found for controled capture of the iodine.
\end{abstract}

Index Terms-Electric breakdown, flashover, gas insulation, sulphur hexafluoride $\left(\mathrm{SF}_{6}\right)$ and trifluoroiodomethane $\left(\mathrm{CF}_{3} \mathbf{I}\right)$.

\section{INTRODUCTION}

$\mathbf{S}$ $\mathrm{F}_{6}$ is an electronegative gas and its dielectric strength is three times higher than that of air [1]. The outstanding properties of $\mathrm{SF}_{6}$ have resulted in its extensive use as the gas medium in high-voltage equipment such as gas-insulated switchgear (GIS) and gas-insulated lines (GIL). However, there is environmental concerns related to $\mathrm{SF}_{6}$ gas. Alternative insulation gases to replace $\mathrm{SF}_{6}$ have been investigated in recent decades and an emerging candidate is trifluoroiodomethane $\left(\mathrm{CF}_{3} \mathrm{I}\right)$ gas. The weak chemical bond $\mathrm{C}-\mathrm{I}$ in $\mathrm{CF}_{3} \mathrm{I}$ means that it can be decomposed quickly in the atmosphere and, therefore, the ozone depletion potential [2] for surface release and the global warming potential [3] of $\mathrm{CF}_{3} \mathrm{I}$ are extremely low. In this way, $\mathrm{CF}_{3} \mathrm{I}$ is considered to be an environmentally friendly alternative to $\mathrm{SF}_{6}$. However, the boiling point of $\mathrm{CF}_{3} \mathrm{I}$ at atmospheric pressure is $-22.5^{\circ} \mathrm{C}$ [4], which would liquefy under typical operating

Manuscript received February 5, 2016; revised May 6, 2016; accepted August 1, 2016. Date of publication September 8, 2016; date of current version March 22 , 2017. This work was supported in part by the Ph.D. studentships from the Engineering and Physical Sciences Research Council, Transformation of the Top and Tail of Energy Networks under Grant EP/I031707/1, and in part by the Power Networks Research Academy. Paper no. TPWRD-00161-2016.

L. Chen, P. Widger, H. Griffiths, and A. Haddad are with the School of Engineering, Cardiff University, Cardiff CF24 3AA, U.K (e-mail: chent3@ cf.ac.uk; widgerp@cf.ac.uk; griffithsh@cf.ac.uk; haddad@cf.ac.uk).

M. S. Kamarudin is with the Universiti Tun Hussein Onn Malaysia, Batu Pahat, Johor 86400, Malaysia (e-mail: saufi@uthm.edu.my).

Color versions of one or more of the figures in this paper are available online at http://ieeexplore.ieee.org.

Digital Object Identifier 10.1109/TPWRD.2016.2602259 pressure of high-voltage GIS/GIL equipment. Therefore, it has to be used in low proportions as part of a binary mixture with $\mathrm{CO}_{2}$ or $\mathrm{N}_{2}$ to reduce the liquefaction temperature. When considering $\mathrm{CF}_{3} \mathrm{I}$ as an alternative to $\mathrm{SF}_{6}$, it is important to take into account that switchgear operated on the medium-voltage $(11 \mathrm{kV})$ network uses $\mathrm{SF}_{6}$ slightly above atmospheric pressure. For this reason, $\mathrm{CF}_{3} \mathrm{I}$ could be considered as a potential replacement candidate for application in medium-voltage switchgear.

This paper provides an overview of the research work into the gas properties that has been conducted on $\mathrm{CF}_{3} \mathrm{I}$ at Cardiff University. Therefore, for completeness it recalls some of the main results that were published earlier and presents more recent research results. In the paper, we describe the experimental investigations carried out on $\mathrm{CF}_{3} \mathrm{I}$ gas mixtures including: a) a comparison of properties between $\mathrm{SF}_{6}$ and $\mathrm{CF}_{3} \mathrm{I} ; \mathrm{b}$ ) breakdown results obtained on rod-plane and plane-plane configurations filled with $\mathrm{CF}_{3} \mathrm{I} / \mathrm{CO}_{2}$ gas mixtures; c) a reduced scale coaxial test system to explore dielectric properties of using $\mathrm{CF}_{3} \mathrm{I}$ gas mixtures for application in GIL; and d) laboratory results of industrial switchgear designed for $\mathrm{SF}_{6}$ gas when the gas is replaced with $\mathrm{CF}_{3} \mathrm{I} / \mathrm{CO}_{2}$ gas mixture.

\section{COMPARISON OF PROPERTIES OF $\mathrm{SF}_{6}$ AND $\mathrm{CF}_{3}$ I GASES AND THEIR MIXTURES}

$\mathrm{SF}_{6}$ and $\mathrm{CF}_{3} \mathrm{I}$ have a number of similar properties: both gases are colourless, odourless and nonflammable. Since $\mathrm{CF}_{3} \mathrm{I}$ has to be used as a mixture, an appropriate $\mathrm{CF}_{3} \mathrm{I}$ gas mixture can be chosen based on numerous properties which are discussed further in this section.

\section{A. Environmental Impacts}

The environmental impact is generally based on two parameters: global warming potential (GWP) and ozone depletion potential (ODP).

GWP is a relative measure to $\mathrm{CO}_{2}$ of the heat absorption capability of a greenhouse gas in the atmosphere. It can be seen from Table I [3] that $\mathrm{SF}_{6}$ has a very high GWP and a long atmospheric lifetime, making it an undesirable gas medium with a high environmental impact. In comparison, $\mathrm{CF}_{3} \mathrm{I}$ has a much lower GWP value and can be considered as an environmentally friendly alternative.

The ODP is the degradation that can be caused to the ozone layer by a greenhouse gas. The $\mathrm{C}-\mathrm{I}$ bond in $\mathrm{CF}_{3} \mathrm{I}$ dissociates due to the absorption of sunlight and, once the released iodine 
TABLE I

Global WARMing PotentiaL (GWP) FOR $\mathrm{CO}_{2}, \mathrm{SF}_{6}$ AND $\mathrm{CF}_{3} \mathrm{I}$ [3]

\begin{tabular}{|c|c|c|c|c|c|}
\hline \multirow[t]{2}{*}{ Chemical Formula } & \multirow[t]{2}{*}{ Lifetime (years) } & \multicolumn{4}{|c|}{ GWP for a Given Time Horizon (years) } \\
\hline & & $\operatorname{SAR}(100)^{1}$ & 20 & 100 & 500 \\
\hline $\mathrm{CO}_{2}$ & - & 1 & 1 & 1 & 1 \\
\hline $\mathrm{SF}_{6}$ & 3200 & 23900 & 15100 & 22200 & 32400 \\
\hline $\mathrm{CF}_{3} \mathrm{I}$ & 0.005 & - & 1 & 1 & $<1$ \\
\hline
\end{tabular}

${ }^{1}$ SAR: second assessment report on climate change by IPCC.

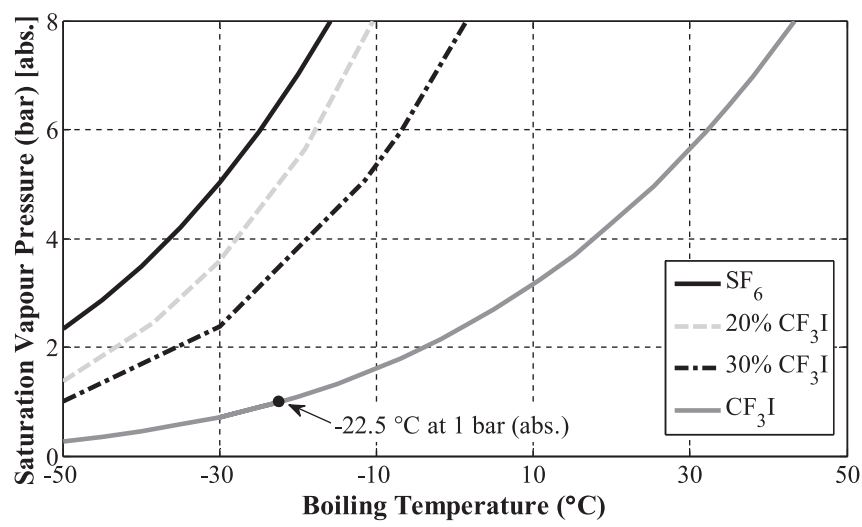

Fig. 1. Saturation vapour pressure vs. boiling temperature for $\mathrm{SF}_{6}, \mathrm{CF}_{3} \mathrm{I}$ and $20 \%$ and $30 \% \mathrm{CF}_{3} \mathrm{I}$ content.

reaches the lower troposphere, it will be removed through rainout. Previous studies have reported ODP values of $<0.008$ for $\mathrm{CF}_{3} \mathrm{I}$, which represents an extremely low impact [5].

\section{B. Liquefaction Conditions of CF3I Gas Mixtures}

The boiling temperature or the saturation vapour pressure of pure $\mathrm{CF}_{3}$ I gas was measured by Duan et al. [4], and an analytical correlation (1) was derived from the experimental data for the vapour pressure calculation of $\mathrm{CF}_{3} \mathrm{I}$.

$$
\ln \left(P / P_{c}\right)=\left(A_{1} \tau+A_{2} \tau^{1.25}+A_{3} \tau^{3}+A_{4} \tau^{7}\right) T_{c} / T
$$

The parameters of (1) were adopted from [4], and the boiling temperatures of $\mathrm{SF}_{6}, \mathrm{CF}_{3} \mathrm{I}$ and $20 \%$ and $30 \% \mathrm{CF}_{3} \mathrm{I}$ content for a pressure range up to 8 bar (abs.) are shown in Fig. 1. These curves were obtained with the assumption that the buffer gas behave as an ideal gas. As the pressure of a gas increases, the dielectric strength also increases. Based on operational experiences of gas-insulated systems, high reliability is found in the range of 4 to 8 bar for insulating gas pressures.

\section{Field Strength Analysis of $\mathrm{CF}_{3} I$ Gas and its Mixtures}

The effective ionisation coefficients of different gases and gas mixtures were computed using BOLSIG+, which applies the two-term approximation of the Boltzmann equation [6]. Fig. 2 shows the pressure-normalised ionisation coefficient ( $\alpha$ $-\eta)$ as a function of $\mathrm{E} / \mathrm{p}$.

The simulation provides an indication on the critical reduced field strength, $(\mathrm{E} / \mathrm{p})_{\text {crit }}$ of various gases or gas mixtures. The simulated values for $\mathrm{CF}_{3} \mathrm{I}$ and $\mathrm{SF}_{6}$ at $(\alpha-\eta)=0$ is con-

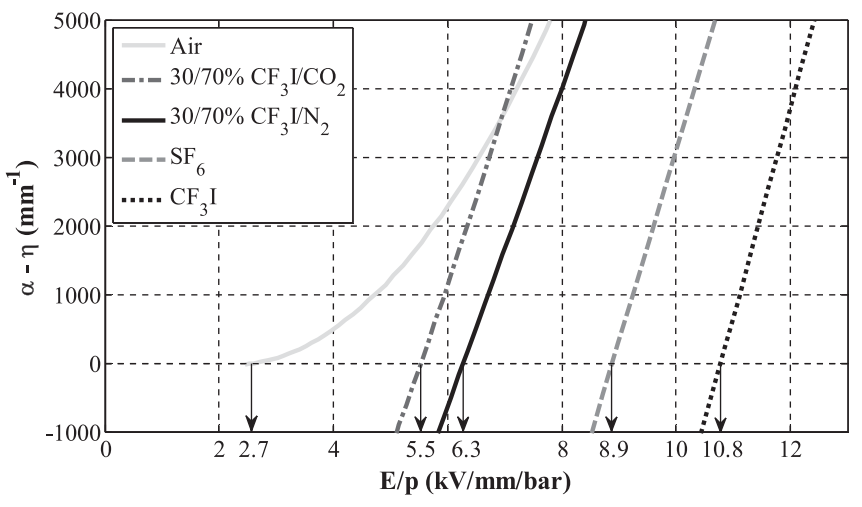

Fig. 2. Effective ionisation coefficients in pure gases (Air, $\mathrm{SF}_{6}$ and $\mathrm{CF}_{3} \mathrm{I}$, and gas mixtures $\left(30 / 70 \% \mathrm{CF}_{3} \mathrm{I} / \mathrm{N}_{2}\right.$ and $\left.30 / 70 \% \mathrm{CF}_{3} \mathrm{I} / \mathrm{CO}_{2}\right)$. Arrows indicate the critical E/p at $(\alpha-\eta)=0$.

sistent with experimental results reported in [7], which have shown that pure $\mathrm{CF}_{3} \mathrm{I}$ has a dielectric strength around 1.2 times higher than that of $\mathrm{SF}_{6}$. The steepness of the slope for $\mathrm{CF}_{3} \mathrm{I}$ and $\mathrm{SF}_{6}$ indicates that $\alpha$ is sensitive to changes in $\mathrm{E} / \mathrm{p}$. The insulation integrity of the gases is precarious near to the $(\mathrm{E} / \mathrm{p})_{\text {crit }}$, since breakdown in $\mathrm{SF}_{6}$ is known to happen very fast as a strong growth of ionisation would occur in the region where $\mathrm{E} / \mathrm{p}>(\mathrm{E} / \mathrm{p})_{\text {crit }}$, especially in the presence of defects on the surface of gas-insulated equipment [1].

$\mathrm{CF}_{3} \mathrm{I}$ gas mixtures show a less linear characteristic than pure $\mathrm{CF}_{3} \mathrm{I}$ and $\mathrm{SF}_{6}$ and are less sensitive to changes in $\mathrm{E} / \mathrm{p}$. The result for the $30 / 70 \% \mathrm{CF}_{3} \mathrm{I}$ gas mixtures were simulated using BOLSIG+ and are found to be in good agreement with the published results in the literature [8]. It was found that the $(\mathrm{E} / \mathrm{p})_{\text {crit }}$ of the $30 / 70 \% \mathrm{CF}_{3} \mathrm{I} / \mathrm{N}_{2}$ gas mixture is higher than the $(\mathrm{E} / \mathrm{p})_{\text {crit }}$ of the $30 / 70 \% \mathrm{CF}_{3} \mathrm{I} / \mathrm{CO}_{2}$ gas mixture, with $6.27 \mathrm{kV} / \mathrm{mm} /$ bar of $5.53 \mathrm{kV} / \mathrm{mm} /$ bar respectively.

\section{By-Products Analysis}

It was reported in [9] that there is a build-up of by-products after a significant number of electrical discharges. For 25, 500, 1000 and 1300 electrical discharges, by-products analysis determined the generation of $\mathrm{C}_{2} \mathrm{~F}_{6}, \mathrm{C}_{2} \mathrm{~F}_{4}, \mathrm{CHF}_{3}, \mathrm{C}_{3} \mathrm{~F}_{8}, \mathrm{C}_{3} \mathrm{~F}_{6}$ and $\mathrm{C}_{3} \mathrm{~F}_{5} \mathrm{I}$ for $\mathrm{CF}_{3} \mathrm{I}$ gas.

An experimental investigation was carried out by Katagiri et al. [10] on the density of by-products such as iodine and fluorine in $\mathrm{CF}_{3} \mathrm{I}$ gas and its mixtures. It was reported that there is a much lower fluorine density measured for $\mathrm{CF}_{3} \mathrm{I}$ than for $\mathrm{SF}_{6}$. It is also encouraging to observe that nearly no fluorine content was detected for the $30 / 70 \% \mathrm{CF}_{3} \mathrm{I} / \mathrm{CO}_{2}$ gas mixture post current interruption. Due to the weak C-I bond, iodine is a likely source of by-product. The results reported in [10] show that a $30 / 70 \% \mathrm{CF}_{3} \mathrm{I} / \mathrm{CO}_{2}$ gas mixture produces only $1 / 3$ of the iodine content in comparison to pure $\mathrm{CF}_{3} \mathrm{I}$ gas when $400 \mathrm{~A}_{\mathrm{rms}}$ was interrupted, which is almost proportional to the percentage of $\mathrm{CF}_{3} \mathrm{I}$ as part of the mixture.

\section{E. Toxicity Review of $\mathrm{CF}_{3} \mathrm{I}$}

$\mathrm{CF}_{3} \mathrm{I}$ is denser than air which means if substantial level of $\mathrm{CF}_{3} \mathrm{I}$ is released and allowed to settle in an enclosed space, then 


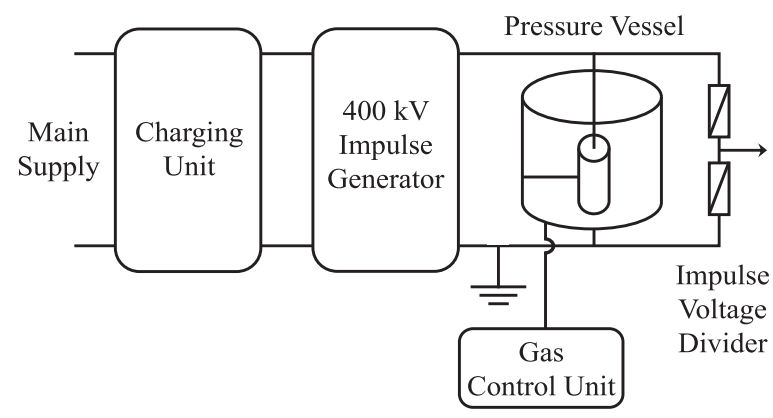

Fig. 3. Test circuit of lightning impulse experimental setup.

it presents the risk of asphyxiation. The median lethal concentration $\left(\mathrm{LC}_{50}\right)$ of $\mathrm{CF}_{3} \mathrm{I}$ was reported to be $27.4 \%$ performed on Sprague-Dawley rats [11], a value that would classify $\mathrm{CF}_{3} \mathrm{I}$ as nontoxic. This is only an approximate value determined using two concentration levels ( 24 and $28.8 \%$ ) for 15 min exposures, which makes the value questionable as $\mathrm{LC}_{50}$ requires at least three concentrations and where the animals are exposed to a longer duration (4 to $6 \mathrm{hrs}$ ).

The US National Research Council's (NRC) committee on toxicology conducted an independent evaluation of the US Army's toxicity review for $\mathrm{CF}_{3} \mathrm{I}$. The investigation shows that the ability of $\mathrm{CF}_{3} \mathrm{I}$ to induce mutagenesis is considered to be equivocal and may warrant further investigation. It was recommended that $\mathrm{CF}_{3} \mathrm{I}$ has no observed adverse level (NOAEL) on cardiac sensitization if the concentration is $0.2 \%$, whereas the lowest observed adverse level (LOAEL) is $0.4 \%$ [12]. However, it was also stated in the compressed gas association (CGA) standard that $\mathrm{CF}_{3} \mathrm{I}$ is a nontoxic gas [13]. Since $\mathrm{CF}_{3} \mathrm{I}$ is proposed only to be used in relatively low proportions as part of a gas mixture in high-voltage equipment, it is, therefore, suggested that the overall toxicity level of the $\mathrm{CF}_{3} \mathrm{I}$ gas mixture would be drastically reduced when mixed with a buffer gas such as $\mathrm{CO}_{2}$ or $\mathrm{N}_{2}$.

\section{LABORATORY TeSt SETUP, EXPERIMENTAL TECHNIQUES AND FABRICATION OF TEST ELECTRODES}

\section{A. Lightning Impulse Test Setup}

In high-voltage experiments, lightning impulse voltages are used to investigate the breakdown mechanisms. A standard lightning impulse voltage $(1.2 / 50)$ reaches its peak voltage in 1.2 microseconds and then gradually declines, eventually reaching zero. The peak value of impulse voltages is measured by a digital oscilloscope $(10 \mathrm{GS} / \mathrm{s}, 600 \mathrm{MHz})$, which is used to record the complete time characteristic of the voltage.

For the laboratory work, a $400 \mathrm{kV}$ Haefely impulse generator was used for the generation of lightning impulse voltages $(1.2 / 50)$ that led to gas discharges in either positive or negative impulse polarity for any chosen test electrode configuration. The circuit diagram for the impulse test set up can be seen in Fig. 3 .

\section{B. Experimental Techniques}

The up-down standard test method was adopted for the breakdown tests [14]. This is a method that determines the $50 \%$

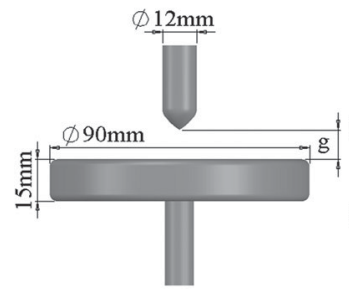

(a)

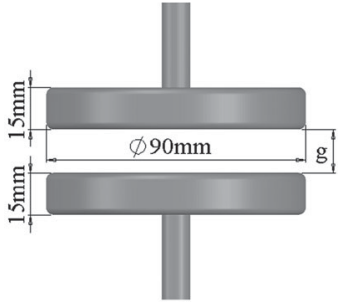

(b)
Fig. 4. (a) Rod-plane and (b) plane-plane electrode configurations.

breakdown voltage $\mathrm{U}_{50}$ of an electrode configuration with a small number of discharges, which requires minimal experimental time and achieves a good level of accuracy. There is a minimum time interval of two minutes between each impulse shot, which allows the gas to recover its insulation strength after a breakdown event. Previous setup test results by the authors show a high level of repeatability, which indicates the time interval between impulses is sufficient. For every test arrangement, a minimum of 30 impulse voltage applications were applied.

For the test on the switchgear, all tests were conducted in accordance with standards BS60060-1 [14] and BS62271-1 [15] for high-voltage switchgear and controlgear.

\section{Fabrication and Preparation of Test Electrodes}

A rod-plane and plane-plane electrode configurations, as shown in Fig. 4, were chosen to represent a non-uniform and a uniform electric field distribution respectively. The rod electrode had a $45^{\circ}$ angle and the tip had a radius of $0.5 \mathrm{~mm}$ and the plane electrodes had a diameter of $90 \mathrm{~mm}$. Each conducting electrode had a M10 size inner thread for fitting onto the highvoltage bushing using an $\varnothing 10 \mathrm{~mm}$ rod. All the rod and plane electrodes were made of a brass alloy.

Prior to any testing, the electrodes were polished using a Strurers Tegramin-25 machine. Polishing cloths and ultra-fine aluminium oxide polishing powder were used to achieve an efficient removal process and apply a smooth surface finish. This is to minimise the effect of surface roughness on the measured breakdown results. After breakdown test series, minor impulse impacts were observed on the surface of the plane electrode, the minor impact markings were useful to indicate the location of flashover in the centre of the contact.

\section{BREAKdown CHARACTERISTICS OF $\mathrm{CF}_{3}$ I Gas MiXtuRes IN UNIFORM AND NON-UNIFORM GEOMETRIES}

To characterise $\mathrm{CF}_{3} \mathrm{I}$ gas mixtures as an insulation medium, lightning impulse experiments with both polarities were conducted on rod-plane and plane-plane electrode configurations. For the investigation in this paper, a mixture ratio of $30 / 70 \%$ for both $\mathrm{CF}_{3} \mathrm{I} / \mathrm{CO}_{2}$ and $\mathrm{CF}_{3} \mathrm{I} / \mathrm{N}_{2}$ gas mixtures were tested.

\section{A. Effect of Gas Pressure, Gap Distance and Impulse Polarity}

Breakdown characteristics of a $30 / 70 \% \mathrm{CF}_{3} \mathrm{I} / \mathrm{CO}_{2}$ gas mixture using rod-plane and plane-plane electrode configurations 


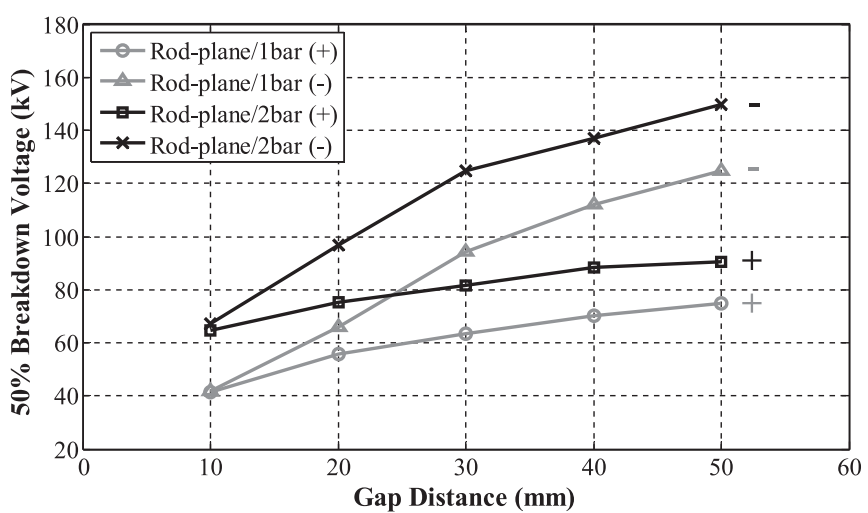

Fig. 5. $\mathrm{U}_{50}$ as a function of gap distance in a rod-plane electrode configuration and investigated for a 30/70\% $\mathrm{CF}_{3} \mathrm{I} / \mathrm{CO}_{2}$ gas mixture at pressures of 1 and 2 bar (abs.) and for both lightning impulse polarities.

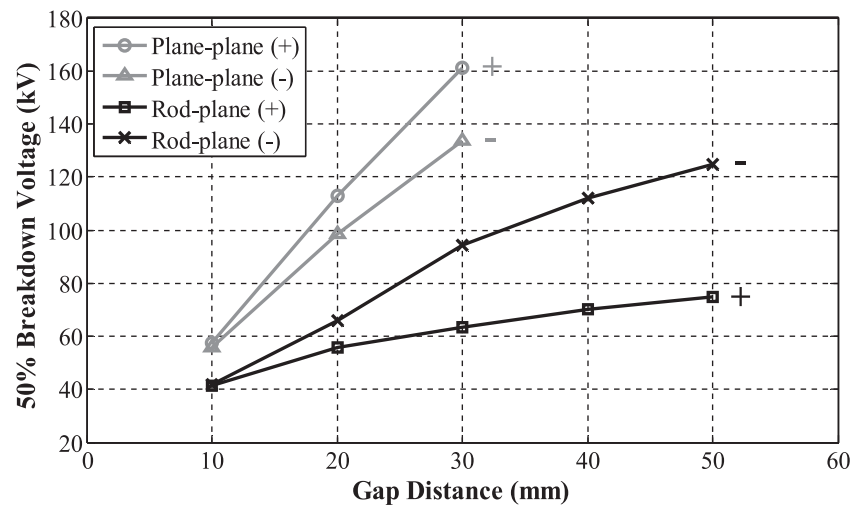

Fig. 6. $\mathrm{U}_{50}$ as a function of gap distance in a plane-plane and a rod-plane electrode configurations, tested using a $30 / 70 \% \mathrm{CF}_{3} \mathrm{I} / \mathrm{CO}_{2}$ gas mixture at 1 bar (abs.) and for both lightning impulse polarities.

were investigated and reported in [16]. The range of experimental data was able to provide an indication on the influence of gas pressure, gap distance and impulse polarities for a $\mathrm{CF}_{3} \mathrm{I} / \mathrm{CO}_{2}$ gas mixture. As pressure increases from 1 to 2 bar, the breakdown voltage increases but at a slower rate, as shown in Fig. 5. However, it is unclear from the available data that higher rate of saturation in the breakdown results is expected at higher gas pressures.

The effect of gap distance was tested for plane-plane and rodplane electrode configurations. The breakdown voltage measured towards higher gap distances is increasing but with decreasing rate, as shown in Fig. 6.

It can be seen from both Figs. 5 and 6 that the breakdown results for negative polarity are higher than those for positive polarity in a rod-plane configuration. In the case of a positive rod, ionization accelerates electron collision in the high field region near the rod. Electrons are readily drawn towards the anode and, with time, the field strength near the rod is sufficiently high to initiate a complete breakdown. For a negative rod, the electrons are accelerated into the low field region by the cathode and, during the process, they become attached to strongly attaching gases like $\mathrm{CF}_{3} \mathrm{I}$ or $\mathrm{SF}_{6}$ [17]. This slows down the ionization process, which then requires a higher voltage to initiate a complete breakdown. Similar breakdown characteristics on

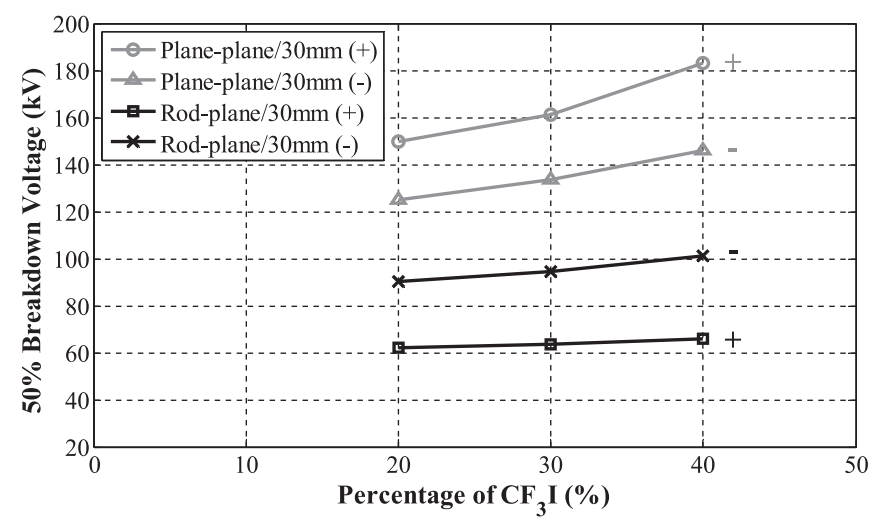

Fig. 7. $\mathrm{U}_{50}$ as a function of $\mathrm{CF}_{3} \mathrm{I} / \mathrm{CO}_{2}$ gas mixtures in a rod-plane electrode configuration for a gap distance of $30 \mathrm{~mm}$ at $1 \mathrm{bar}$ (abs.) and for both lightning impulse polarities.

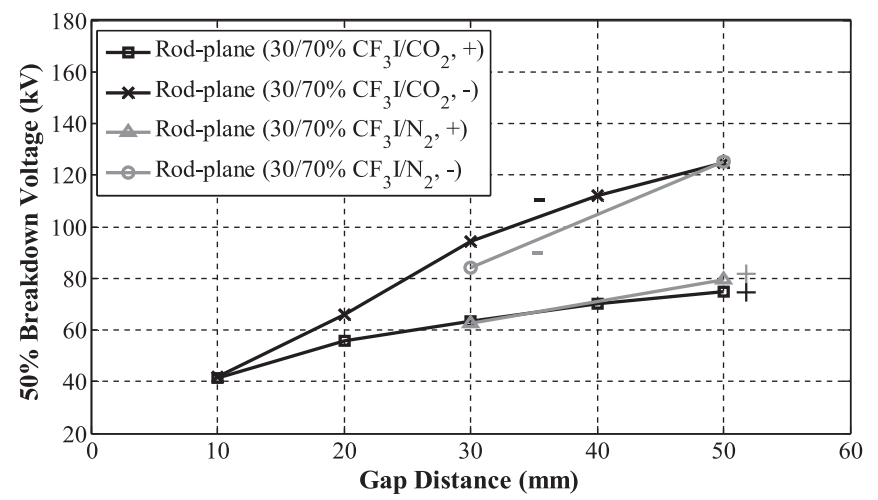

Fig. 8. $\mathrm{U}_{50}$ as a function of gap distance of 10 to $50 \mathrm{~mm}$ in a rod-plane electrode configuration, tested using a mixture ratio of $30 / 70 \%$ for both $\mathrm{CF}_{3} \mathrm{I} / \mathrm{CO}_{2}$ and $\mathrm{CF}_{3} \mathrm{I} / \mathrm{N}_{2}$ gas mixtures at 1 bar (abs.) and for both lightning impulse polarities.

a rod-plane electrode for standard lightning impulses $(1.2 / 50)$ were also reported by other researchers for $\mathrm{CF}_{3} \mathrm{I}$ [18].

\section{B. Effect of Mixture Content and Buffer Gas}

Tests were carried out for $\mathrm{CF}_{3} \mathrm{I} / \mathrm{CO}_{2}$ gas mixture ratios of $20 / 80 \%, 30 / 70 \%$ and $40 / 60 \%$ at a pressure of 1 bar (abs.) in rod-plane and plane-plane electrode configurations for a fixed gap distance of $30 \mathrm{~mm}$. As can be seen, an increase in $\mathrm{CF}_{3} \mathrm{I}$ content results in a higher breakdown strength, as illustrated in Fig. 7. However, for a binary gas mixture with high $\mathrm{CF}_{3} \mathrm{I}$ content, lower pressures are required to avoid liquefaction, and more by-products are likely to be generated per breakdown.

An investigation was also conducted for $\mathrm{CF}_{3} \mathrm{I}$ gas mixtures mixed with $\mathrm{CO}_{2}$ and $\mathrm{N}_{2}$ as buffer gas. For a 30/70\% mixture ratio, the test results are shown in Figs. 8 and 9. It can be seen in Fig. 8 that there is a small difference in breakdown results of a rod-plane configuration for both $\mathrm{CF}_{3} \mathrm{I} / \mathrm{CO}_{2}$ and $\mathrm{CF}_{3} \mathrm{I} / \mathrm{N}_{2}$ gas mixtures under both impulse polarities. However, changing the buffer gas has a more profound effect on $\mathrm{U}_{50}$ in a plane-plane configuration. Results for $\mathrm{CF}_{3} \mathrm{I} / \mathrm{N}_{2}$ are comparably lower than their $\mathrm{CF}_{3} \mathrm{I} / \mathrm{CO}_{2}$ counterpart (see Fig. 9). 


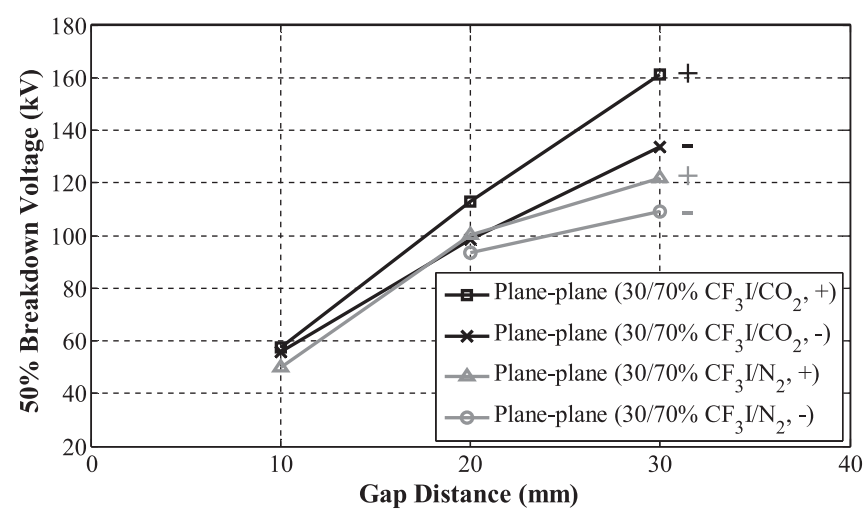

Fig. 9. $\mathrm{U}_{50}$ as a function of gap distance of 10 to $30 \mathrm{~mm}$ in a plane-plane electrode configuration, tested using a mixture ratio of $30 / 70 \%$ for both $\mathrm{CF}_{3} \mathrm{I} / \mathrm{CO}_{2}$ and $\mathrm{CF}_{3} \mathrm{I} / \mathrm{N}_{2}$ gas mixtures at 1 bar (abs.) and for both lightning impulse polarities.

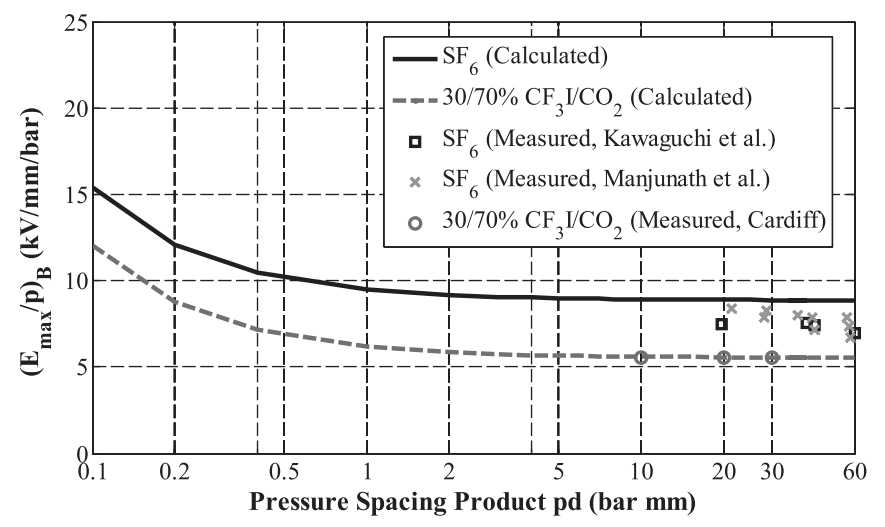

Fig. 10. Characteristics of $\left(\mathrm{E}_{\mathrm{max}} / \mathrm{p}\right)_{\mathrm{B}}$ in uniform gaps for $\mathrm{SF}_{6}$ and $30 / 70 \%$ $\mathrm{CF}_{3} \mathrm{I} / \mathrm{CO}_{2}$ gas mixture for both calculated and meaasured data and for positive lightning impulse.

\section{Breakdown Field Strength of $30 / 70 \% \mathrm{CF}_{3} \mathrm{I} / \mathrm{CO}_{2}$ Gas Mixture in Uniform and Non-Uniform Geometries}

In order to generalise the information obtained from the experiment, the measured $\mathrm{U}_{50}$ values are converted into the pressurenormalised maximum breakdown field strength $\left(\mathrm{E}_{\max } / \mathrm{p}\right)_{\mathrm{B}}$. This can be calculated using (2) which is adopted from [19].

$$
\left(E_{\max } / p\right)_{B}=(E / p)_{\mathrm{crit}}+\frac{K}{k(p d)}
$$

where $(\mathrm{E} / \mathrm{p})_{\text {crit }}$ is the critical reduced field strength, $\mathrm{k}$ is the primary ionization coefficient and $\mathrm{K}$ is the streamer mechanism $(\mathrm{K}=18)$. The $(\mathrm{E} / \mathrm{p})_{\text {crit }}$ and $\mathrm{k}$ values are obtained using BOLSIG + for when $(\alpha-\eta)=0$ for each gas or gas mixture.

By adopting (2), the breakdown field strength values for $\mathrm{SF}_{6}$ and $30 / 70 \% \mathrm{CF}_{3} \mathrm{I} / \mathrm{CO}_{2}$ gas mixture were calculated, and are shown in Fig. 10. As can be observed, there is good agreement between the measured and calculated results for $30 / 70 \%$ $\mathrm{CF}_{3} \mathrm{I} / \mathrm{CO}_{2}$ gas mixture [16]. The $\mathrm{SF}_{6}$ data [20]-[21] appears to show less agreement, which may be due to surface defects as opposed to the mirror finish used in $\mathrm{CF}_{3} \mathrm{I}$ testing. $\mathrm{SF}_{6}$ is known to be very sensitive to change in $\mathrm{E} / \mathrm{p}$, especially in the presence of defects on the surface of the electrodes.

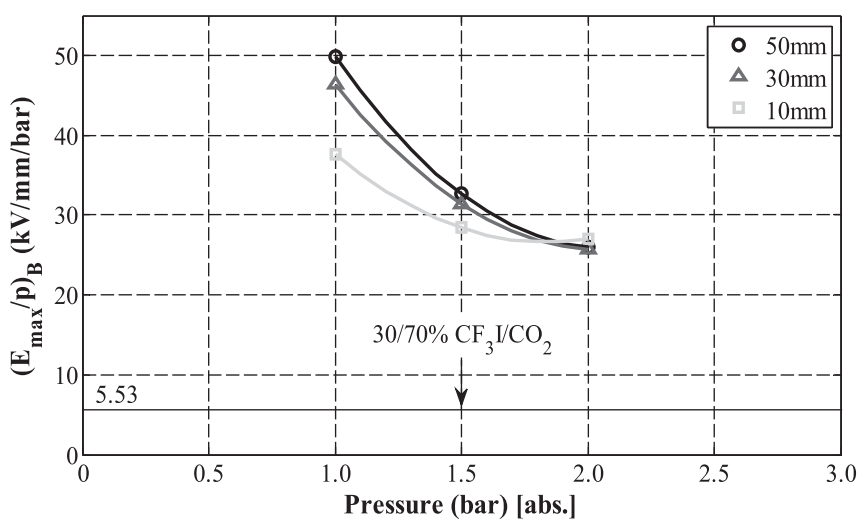

Fig. 11. Characteristics of $\left(\mathrm{E}_{\mathrm{max}} / \mathrm{p}\right)_{\mathrm{B}}$ for $30 / 70 \% \mathrm{CF}_{3} \mathrm{I} / \mathrm{CO}_{2}$ gas mixture at pressure of 1 to 2 bar (abs.), tested on non-uniform gaps and for positive lightning impulse.

In the case of non-uniform field gaps, Equation (3) was proposed by Howard [22] for calculating the field strength in nonuniform field breakdown for electronegative gas.

$$
\left(E_{\max } / p\right)_{B}=\frac{2 \cdot U_{b}}{R \cdot \ln (4 g / R)}
$$

where $\mathrm{R}$ is the radius of curvature of the point tip, $\mathrm{g}$ is the gap spacing and $\mathrm{U}_{\mathrm{b}}$ is the measured breakdown voltage.

The breakdown field strength can also be obtained using COMSOL software, which require the dimension of the test configuration and the measured breakdown voltage. By using COMSOL, the $\left(\mathrm{E}_{\max } / \mathrm{p}\right)_{\mathrm{B}}$ values were obtained and are shown in Fig. 11 for $30 / 70 \% \mathrm{CF}_{3} \mathrm{I} / \mathrm{CO}_{2}$ gas mixture.

Based on the available data, the $\left(\mathrm{E}_{\max } / \mathrm{p}\right)_{\mathrm{B}}$ is shown to decrease with pressure towards the $(\mathrm{E} / \mathrm{p})_{\text {crit }}$ of the test gas mixture. It has been observed in the literature for $\mathrm{SF}_{6}$ in quasi-uniform field gaps, that the $\left(\mathrm{E}_{\max } / \mathrm{p}\right)_{\mathrm{B}}$ drops below the $(\mathrm{E} / \mathrm{p})_{\text {crit }}$ at higher gas pressures [23]. It is unclear from Fig. 11 whether a similar trend characteristic can be expected for a $\mathrm{CF}_{3} \mathrm{I} / \mathrm{CO}_{2}$ gas mixture and in non-uniform field gaps. Further experimental works are required at higher pressures and more choice of curvature radius on the rod tip.

\section{INVESTIGATION OF 30/70\% $\mathrm{CF}_{3}$ I GAS MIXTURES IN COAXIAL GIL TEST SYSTEM}

In gas-insulated equipment, a gas can be used as an insulation medium for application in GIL. Construction of a full-scale GIL is quite costly. For the initial experimental work, a reduced-scale coaxial GIL test system that has similar electric field distribution as a full-scale GIL was designed, developed and fabricated. The initial test results are presented in this section to provide an indication on the breakdown strength of $\mathrm{CF}_{3} \mathrm{I}$ gas mixtures and the feasibility for application in GIL.

\section{A. Dimensioning of Coaxial System}

Fig. 12 depicts a proposed coaxial cylindrical structure for the scaled test GIL, with $R_{a}$ the outer conductor radius and $R_{b}$ the inner enclosure radius. 


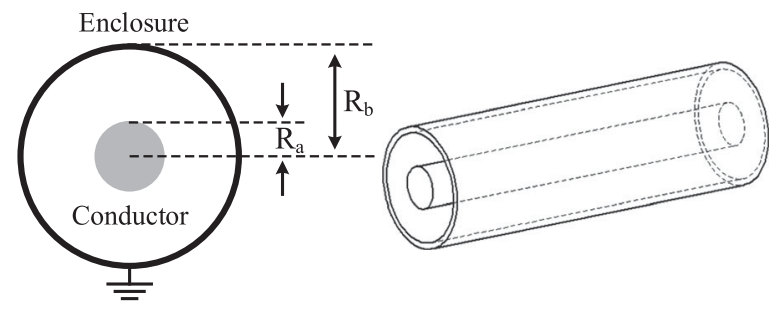

Fig. 12. Cross-section view of a coaxial geometry.

Given the known electric field distribution in a coaxial system, the highest field is expected at the surface of the inner conductor, from where breakdown is likely to be initiated. Equation (4), which gives the maximum field at the inner conductor surface, is used to calculate the optimised radii $R_{a}$ and $R_{b}$ for the scaled prototype. For this work, $R_{a}$ and $R_{b}$ need to be small enough so that the whole GIL prototype fits inside the available test pressure vessel and can withstand the voltage limitation of the high-voltage bushing of the vessel ( $170 \mathrm{kV}$ lightning impulse). As a result, for the $30 / 90 \mathrm{~mm}$ coaxial test system, the test was only conducted up to 0.5 bar (abs.).

$$
E=\frac{U}{R_{a} \cdot \ln \left(R_{b} / R_{a}\right)}
$$

The breakdown electric field magnitude, $\mathrm{E}_{\mathrm{b}}$, is obtained for an applied voltage $\mathrm{U}_{\mathrm{b}}$ on the inner conductor. In this case, (4) can be re-written as (5).

$$
U_{b}=E_{b} \cdot R_{a} \cdot \ln \left(\frac{R_{b}}{R_{a}}\right)
$$

An important factor that needs to be taken into consideration for the design is the optimisation of the gap ratio, which improves field uniformity in a coaxial geometry. As demonstrated in [19], [24], designing the coaxial system so that the quantity $\ln \left(R_{b} / R_{a}\right)$ has a value of unity is considered to satisfy the optimal condition. If $\mathrm{R}_{\mathrm{b}}$ is fixed and $\mathrm{E}_{\mathrm{b}}$ assumed constant, the optimal design for our coaxial geometry was achieved adopting $\ln \left(\mathrm{R}_{\mathrm{b}} / \mathrm{R}_{\mathrm{a}}\right) \approx 1$.

As reported previously [19], [24]-[25], operational GIL systems worldwide have adopted this optimal ratio for their geometric dimensioning. AZZ CGIT, a major manufacturer of GIL, gives details of the dimensions of GIL systems [25] with rated voltages of $145 \mathrm{kV}$ to $1200 \mathrm{kV}$. Here, we plot in Fig. 13 the equivalent lightning impulse withstand voltages against the geometric ratios of the GIL.

As can be observed on the figure, most of the GIL dimensions have ratios of 1 to 2.718 (optimal) or 3. However, in the case of $800 \mathrm{kV}$ and $1200 \mathrm{kV}$ rated GIL, the geometric ratio tends to be much larger than that of lower rated GIL. This may indicate that the field uniformity in the GIL is less important than the gap spacing for very high voltage applications. Such effects were investigated for $\mathrm{CF}_{3}$ I gas mixtures in [26], [27], with the diameter of the outer electrode fixed and using different radii of inner conductors. The conclusion from this investigation indicates that, in coaxial test systems, the highest breakdown strength is dependent on the quantity $\ln \left(\mathrm{R}_{\mathrm{b}} / \mathrm{R}_{\mathrm{a}}\right)$, and is independent of the test gas or gas mixture.

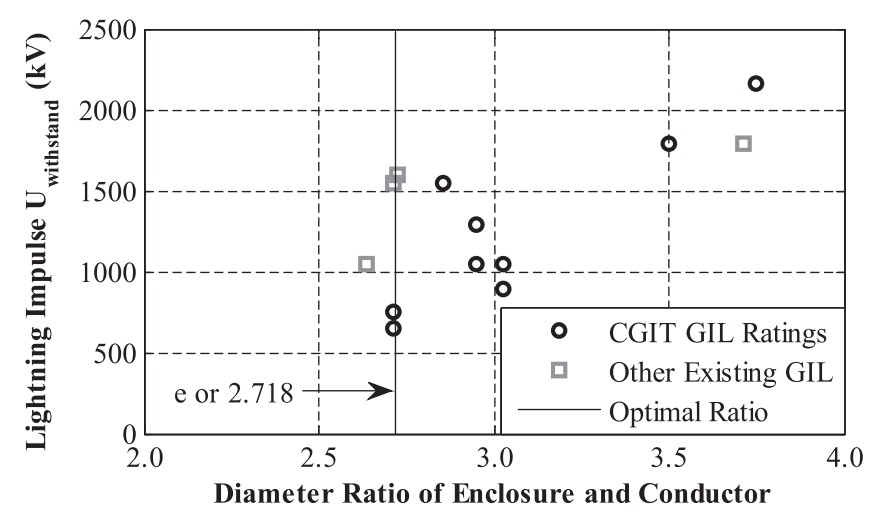

Fig. 13. Relationship between lightning impulse withstand voltage and dimensions in existing GIL systems.

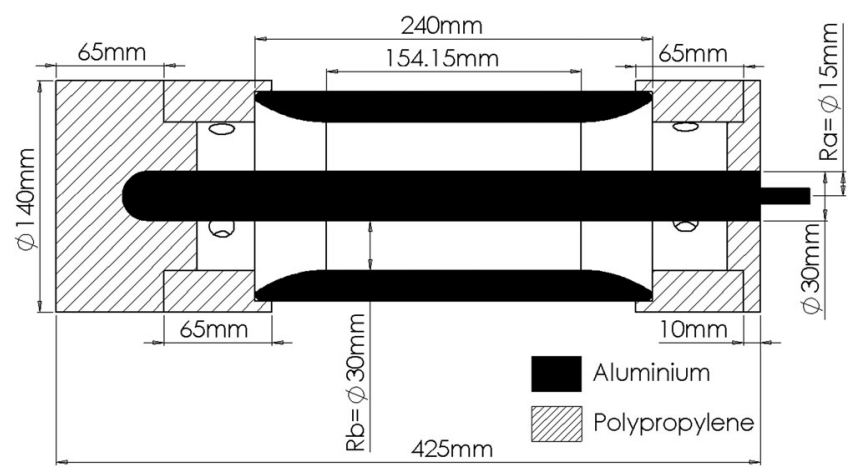

Fig. 14. Design schematic of constructed reduced-scale coaxial GIL laboratory system. The values of " $\mathrm{R}_{\mathrm{a}}$ " and " $\mathrm{R}_{\mathrm{b}}$ " correspond to the radius of outer conductor and inner enclosure.

\section{B. Geometric Dimensioning of the Prototype}

In this investigation, the laboratory coaxial test GIL scaled prototypes were designed with ratios enclosure to conductor between 1 and 3. Such ratios are similar to those adopted for the majority of existing GIL systems at $400 \mathrm{kV}$. In other work by the authors, tests were conducted on a coaxial test system of $10 / 30 \mathrm{~mm}$ [26]. The work in this section extended the geometry to $30 / 90 \mathrm{~mm}$. Results of $\mathrm{CF}_{3} \mathrm{I}$ gas mixtures at a larger coaxial electrode configuration allows us to draw conclusions on extrapolations of breakdown voltages.

Fig. 14 illustrates the geometry details of the constructed GIL laboratory prototype. A curvature radius was implemented on the inner wall of the outer conductor to reduce end effects on electric field magnitude, and this is expected to reduce the likelihood of breakdown at the edges of the enclosure.

The conductor length was designed in such a way that it can be positioned well inside the support insulator. Consequently, the clearance gap between the conductor tip and the enclosure wall was increased significantly.

\section{Simulation Modelling}

$$
U_{s}=E_{\text {crit }} \cdot\left(R_{b}-R_{a}\right)
$$

When the critical field strength, $\mathrm{E}_{\text {crit }}$, of the insulating gas mixture is exceeded at the conductor surface in a coaxial test system with a geometric ratio $R=R_{b} / R_{a}$, corona will 


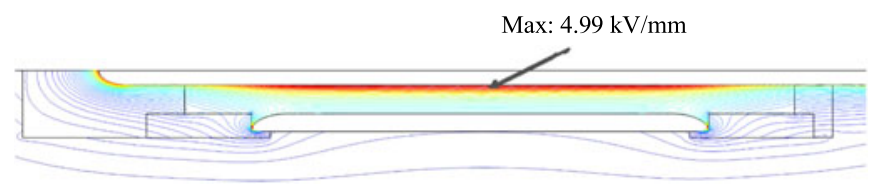

Fig. 15. Computed electric field distribution in coaxial rig for an applied voltage of $83 \mathrm{kV}$ (the maximum electric field occurs around the centre region).

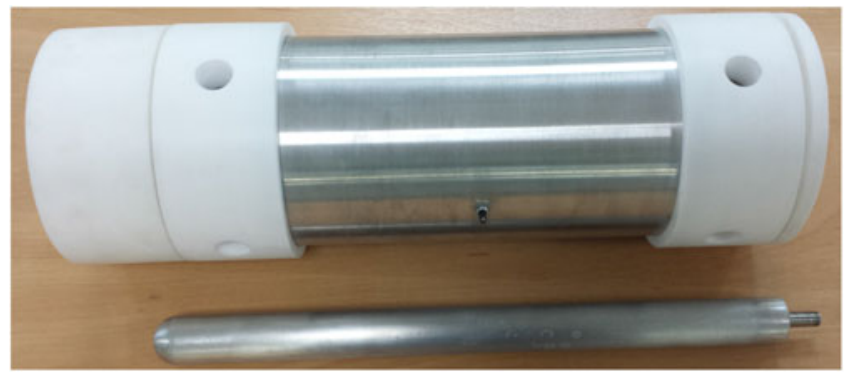

Fig. 16. Photograph of the reduced-scale coaxial test system showing the holes in the insulators to allow easy gas circulation.

TABLE II

COMPARISON OF MEASURED BREAKDOWN VOLTAGE AT 0.5 BAR (ABS.) FOR $30 / 70 \% \mathrm{CF}_{3}$ I GAS MIXTURES

\begin{tabular}{lcc}
\hline \hline Gas Mixture & Positive (kV) & Negative (kV) \\
\hline $30 / 70 \% \mathrm{CF}_{3} \mathrm{I} / \mathrm{CO}_{2}$ & 78.4 & 75.2 \\
$30 / 70 \% \mathrm{CF}_{3} \mathrm{I} / \mathrm{N}_{2}$ & 78.2 & 80.0 \\
\hline \hline
\end{tabular}

be initiated. The inception critical field occurs at a voltage $\mathrm{U}>\mathrm{U}_{\text {inception. }}$. Without formation of any leader channel, the streamer breakdown voltage $\mathrm{U}_{\mathrm{S}}$ is expressed as (6).

In order to identify regions of high field and fine tune the geometry, a numerical simulation of the coaxial system was performed using COMSOL multiphysics. As expected within the design, and can be observed on Fig. 15, the maximum electric field is computed around the central region of the surface of the inner conductor. The field strength is lower at the ends of the enclosure, which is facilitated by the profiled design. Such design will minimise breakdown occurrences at the ends of the test system and will encourage more breakdown events to occur around the central region.

A coaxial test system with inner/outer cylinder geometry of $30 / 90 \mathrm{~mm}$ was fabricated to represent a reduced-scale coaxial GIL test system (Fig. 16). Aluminium was used to machine both the enclosure and the conductor, and the insulating spacers and holders were made from polypropylene. As clearly visible on the photo of Fig. 16, a number of holes were machined in the insulators to facilitate easy and free circulation of the $\mathrm{CF}_{3} \mathrm{I}$ gas mixture throughout the coaxial test system. In order to connect the tip of the conductor to the bushing, a $10 \mathrm{~mm}$ thread was used.

\section{Results and Discussions}

Tests were conducted on the coaxial test system to examine the breakdown performance of $\mathrm{CF}_{3} \mathrm{I}$ gas mixture in a coaxial GIL test configuration. The results are shown in Table II, at a
TABLE III

Predicted and Measured MaXimum Electric Field Magnitudes ( 0.5 BAR (ABS.) USING 30/70\% $\mathrm{CF}_{3}$ I GAS MiXTURES UNDER Positive LightNING IMPULSE)

\begin{tabular}{lcc}
\hline \hline & $\begin{array}{c}30 / 70 \% \mathrm{CF}_{3} \mathrm{I} / \mathrm{CO}_{2} \\
(\mathrm{kV} / \mathrm{mm} / \mathrm{bar})\end{array}$ & $\begin{array}{c}30 / 70 \% \mathrm{CF}_{3} \mathrm{I} / \mathrm{N}_{2} \\
(\mathrm{kV} / \mathrm{mm} / \mathrm{bar})\end{array}$ \\
\hline Calculated $\mathrm{E}_{\max }$ & 5.03 & 5.71 \\
Simulated $\mathrm{E}_{\max }$ & 4.99 & 5.66 \\
Experimental $\left(\mathrm{E}_{\max } / \mathrm{p}\right)_{\mathrm{B}}$ & 4.76 & 4.75 \\
\hline \hline
\end{tabular}

low pressure of $0.5 \mathrm{bar}$ (abs.), the measured results are comparable for both $\mathrm{CF}_{3} \mathrm{I} / \mathrm{CO}_{2}$ and $\mathrm{CF}_{3} \mathrm{I} / \mathrm{N}_{2}$ gas mixtures. For a coaxial geometry of $11.1 / 28.5 \mathrm{~mm}$ with a gap of $8.7 \mathrm{~mm}$, the $\mathrm{U}_{50}$ at 0.5 bar (abs.) for $30 / 70 \% \mathrm{CF}_{3} \mathrm{I} / \mathrm{CO}_{2}$ gas mixture was reported to be $31 \mathrm{kV}$ [27]. In comparison, the $30 / 90 \mathrm{~mm}$ coaxial test system is around 3.4 times larger in terms of the dimensions of the gap spacing but the breakdown voltage is only 2.5 times higher in relation to $\mathrm{U}_{50}$. This suggests that $\mathrm{U}_{50}$ is not increasing linearly with gap spacing as the geometric ratio of the two coaxial test systems are different. This also indicates that the optimal ratio for designing an $\mathrm{SF}_{6}$ coaxial test system applies to other gases such as $\mathrm{CF}_{3} \mathrm{I}$. The results in Table II show that $\mathrm{CF}_{3} \mathrm{I} / \mathrm{CO}_{2}$ and $\mathrm{CF}_{3} \mathrm{I} / \mathrm{N}_{2}$ gas mixtures had polarity effects opposite to each other. This requires further investigation in order to establish a more definitive conclusion regarding the polarity effect introduced by the buffer gas.

Table III summarises the measured and predicted electric field values. Under atmospheric pressure at $0.5 \mathrm{bar}$ (abs.), if the primary streamer extends to bridge the inter-electrode gap in the coaxial system, a streamer breakdown will be initiated when $U_{b}=U_{S}$. Subsequently, this value is used in (4) to calculate $\mathrm{E}_{\max }$ and in the numerical computation to determine the electric field distribution and its associated $\mathrm{E}_{\max }$ magnitude. Furthermore, the measured $\mathrm{U}_{50}$ was utilised in (7) to calculate $\left(E_{\max } / p\right)_{B}$ value.

$$
\left(\mathrm{E}_{\max } / \mathrm{p}\right)_{\mathrm{B}}=\frac{\mathrm{U}_{50}}{\mathrm{R}_{\mathrm{a}} \cdot \ln \left(\mathrm{R}_{\mathrm{b}} / \mathrm{R}_{\mathrm{a}}\right) \cdot \mathrm{p}}
$$

Using these various approaches to determine $\mathrm{E}_{\max }$, i.e. measurements, simplified equation and full numerical computations, good agreement was obtained as can be seen in Table III.

However, there is a potential drop in the measured $U_{50}$ for longer gap distances and higher pressures, which may be attributed to the formation of a self-propagating leader channel. This channel, in turn, may initiate a leader breakdown across the coaxial electrode gap. Work is on-going within the research group to develop a mathematical model which takes into account the drop in potential and its relationship with the streamer/leader processes. This will be communicated in a future publication.

\section{INVESTIGATION OF $30 / 70 \% \mathrm{CF}_{3} \mathrm{I} / \mathrm{CO}_{2}$ GAS MiXTURE FOR APPLICATION IN SWITCHGEAR}

With the promising insulation properties of the 30/70\% $\mathrm{CF}_{3} \mathrm{I} / \mathrm{CO}_{2}$ gas mixture, measured by the authors and other re- 


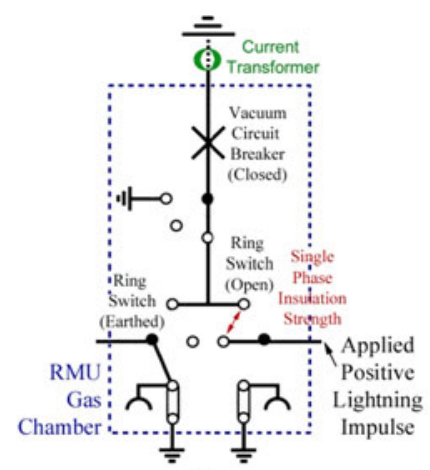

(a)

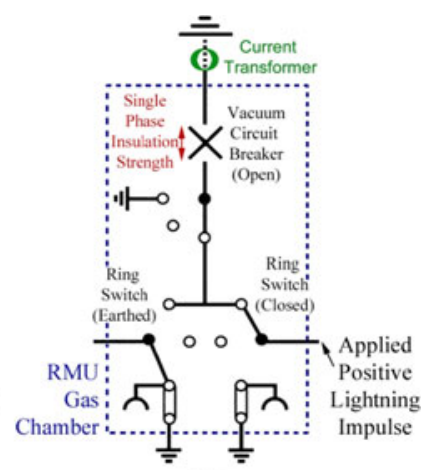

(b)
Fig. 17. Test arrangements for RMU filled with $30 / 70 \% \mathrm{CF}_{3} \mathrm{I} / \mathrm{CO}_{2}$ gas mixture. (a) Test on ring switch, (b) Test on vacuum circuit breaker.

\section{TABLE IV}

NUMBER OF BREAKDOWN EVENTS/NUMBER OF SHOTS FOR BREAKDOWN Tests on 30/70\% $\mathrm{CF}_{3} \mathrm{I} / \mathrm{CO}_{2}$ Gas Mixture Tested With $75 \mathrm{KV}$ Positive LIGHTNING IMPULSES

\begin{tabular}{lcc}
\hline \hline No. of Gas Breakdown & Ring Switch & Circuit Breaker \\
\hline Phase 1 & $0 / 25$ & $0 / 50$ \\
Phase 2 & $0 / 25$ & $0 / 50$ \\
Phase 3 & $0 / 25$ & $0 / 50$ \\
RMU Average & $0 / 75$ & $0 / 150$ \\
\hline \hline
\end{tabular}

searchers, a trial test programme was carried out using this gas mixture as the insulation gas in a commercial $\mathrm{SF}_{6}$-filled ring main unit (RMU). The RMU consists of two low-current ring switches and a tee-off vacuum circuit breaker that is housed in an $\mathrm{SF}_{6}$ gas insulated chamber. Fig. 17 shows a schematic of the tested RMU. The test setup for the low-current switches is indicated in Fig. 17(a) whilst the test arrangement for the circuit breaker is illustrated in Fig. 17(b). During the test campaign, a 1.4 bar (abs.) rated filling pressure of the RMU was used for the $30 / 70 \% \mathrm{CF}_{3} \mathrm{I} / \mathrm{CO}_{2}$ gas mixture.

The $\mathrm{SF}_{6}$-filled RMU has a rated impulse withstand voltage of $75 \mathrm{kV}$. The RMU filled with $30 / 70 \% \mathrm{CF}_{3} \mathrm{I} / \mathrm{CO}_{2}$ was, therefore, tested in accordance with procedure B as specified in BS600601 [14]. This test procedure has been adapted for switchgear and controlgear as described in BS62271-1 [15]. For the breakdown voltage tests, a series of $75 \mathrm{kV}$ positive lightning impulses were applied to each phase in turn. For the switch tests (Fig. 17(a)), 25 impulses were applied to each phase to determine the withstand strength of the $\mathrm{CF}_{3} \mathrm{I} / \mathrm{CO}_{2}$ gas mixture. On the other hand, for the vacuum circuit breaker tests (Fig. 17(b)), two sets of 25 impulses were used on each phase of the RMU. In all tests, a current transformer measurement was utilised to indicate gas breakdown events within the RMU equipment.

The breakdown test results are summarised in Table IV. As can be observed, for the RMU filled with $30 / 70 \% \mathrm{CF}_{3} \mathrm{I} / \mathrm{CO}_{2}$ gas mixture, no breakdown event was recorded for the switch and breaker tests. Such observation allows us to suggest that the $30 / 70 \% \mathrm{CF}_{3} \mathrm{I} / \mathrm{CO}_{2}$ gas mixture is a potential candidate to replace $\mathrm{SF}_{6}$ gas for insulation duties in $11 \mathrm{kV}$ RMU.

In this investigation, however, the current interruption capability of the $30 / 70 \% \mathrm{CF}_{3} \mathrm{I} / \mathrm{CO}_{2}$ gas mixture has not been as- sessed experimentally due to lack of a suitable high current test source. Therefore, future work is planned to explore the current interruption capability of such gas mixture.

\section{CONCLUSION}

This paper highlights the results of work conducted on $\mathrm{CF}_{3} \mathrm{I}$ gas mixtures as potential replacements for $\mathrm{SF}_{6}$ insulation gas in high-voltage equipment. Tests were conducted on several test configurations (rod-plane, plane-plane and coaxial GIL) to characterise the electrical performance of $\mathrm{CF}_{3} \mathrm{I}$ gas mixtures. The effect of gas pressure, gap distance, impulse polarity, mixture content and buffer gas were investigated experimentally. The breakdown test results obtained in this work indicate that the insulation properties of the proposed gas mixture could be a practical alternative candidate to replace $\mathrm{SF}_{6}$ gas in GIL insulation applications. However, $\mathrm{CF}_{3} \mathrm{I}$ current interruption capabilities have not been proven yet, and further work is needed in this area. The build-up of iodine deposition after electrical discharge was observed and its effect need to be quantified if current interruption is to be considered. Again, this needs to be further investigated.

In addition, trial laboratory tests are underway on a full-scale $400 \mathrm{kV}$ GIL demonstrator that has been assembled at Cardiff University. As the demonstrator was designed for $\mathrm{SF}_{6}$, this work will address the issues associated with retrofitting existing $\mathrm{SF}_{6}$ equipment with the proposed $\mathrm{CF}_{3} \mathrm{I}$ gas mixtures. Work on this full-scale demonstrator will provide a better assessment of the capabilities of $\mathrm{CF}_{3}$ I gas mixtures in full practical GIL systems at transmission voltages.

Further experimentation is required on coaxial GIL test system $(30 / 90 \mathrm{~mm})$ at higher gas pressure and work on practical circuit breaker contact electrode configurations using a $\mathrm{CF}_{3} \mathrm{I}$ gas mixture is also envisaged.

\section{REFERENCES}

[1] O. Farish, M. D. Judd, B. F. Hampton, and J. S. Pearson, "SF6 insulation systems and their monitoring," Advances in High Voltage Engineering, A. Haddad and D. Warne, Eds. London, U.K.: IET, 2009, ch. 2, pp. 38-45.

[2] L. G. Christophorou and J. K. Olthoff, "Electron interactions with CF3I," J. Phys. Chem. Ref. Data, vol. 29, no. 4, pp. 553-569, 2000.

[3] EPA 430-R-02-003, "Inventory of U.S. greenhouse gas emissions and sinks: 1990-2000," Office of Atmospheric Programs, U.S. Environmental Protection Agency, Washington, DC, USA, 2002.

[4] Y. Y. Duan, M. S. Zhu, and L. Z. Han, "Experimental vapor pressure data and a vapor pressure equation for trifluoroiodomethane (CF3I)," Fluid Phase Equilibria, vol. 121, pp. 227-234, 1996.

[5] S. Solomon, B. Burkholder, A. R. Ravishankara, and R. Garcia, "Ozone depletion and global warming potentials of CF3I," J. Geophys. Res., vol. 99, no. D10, pp. 20929-20935, 1994.

[6] G. J. M. Hagelaar and L. C. Pitchford, "Solving the Boltzmann equation to obtain electron transport coefficients and rate coefficients for fluid models," Plasma Sources Sci. Technol., vol. 14, no. 4, pp. 722-733, 2005.

[7] J. Urquijo, A. Mitrani, G. Ruiz-Vargas, and E. Basurto, "Limiting field strength and electron swarm coefficients of the CF3I-SF6 gas mixture," J. Phys. D, Appl. Phys., vol. 44, 2011, Art. no. 342001.

[8] D. Tanaka, A. Kumada, and K. Hidaka, "Numerical simulation of streamer development in CF3I-N2 gas mixtures," presented at the Int. Symp. High Voltage Eng., Hannover, Germany, 2011.

[9] T. Takeda, S. Matsuoka, A. Kumada, and K. Hidaka, "By-product generation through electrical discharge in CF3I gas and its effect to insulation characteristics," IEEJ Trans. Power Energy, vol. 131, no. 10, pp. 859-864, Jan. 2011. 
[10] H. Katagiri, H. Kasuya, H. Mizoguchi, and S. Yanabu, "Investigation of the performance of CF3I gas as a possible substitute for SF6," IEEE Trans. Dielectr. Elect. Insul., vol. 15, no. 5, pp. 1424-1429, Oct. 2008.

[11] W. C. Mccain and J. Macko, "Toxicity review for iodotrifluoromethane (CF3I)," in Proc. Halon Options Tech. Working Conf., 1999, Albuquerque, NM, USA, pp. 242-253.

[12] Subcommittee on Iodotrifluoromethane, Iodotrifluoromethane: Toxicity Review, Washington, DC, USA: National Academy Press, 2004.

[13] Standard for the Classification of Toxic Gas Mixtures, 3rd ed. Compressed Gas Association, CGA P-20, 2013.

[14] High-Voltage Test Techniques_Part 1: General Definitions and Test Requirements, British Standard Institution, BS EN 60060-1, 2010.

[15] High-Voltage Switchgear and Controlgear-Part 1: Common Specifications, British Standard Institution, BS EN 62271-1, 2008.

[16] M. S. Kamarudin, A. Haddad, and S. J. Macgregor, "Experimental investigation of CF3I-CO2 gas mixtures under lightning impulses," presented at the 20th Int. Conf. Gas Discharges Appl., Orleans, France, 2014.

[17] L. G. Christophorou, J. K. Olthoff, and D. S. Green, "Gases for electrical insulation and arc interruption: Possible present and future alternatives to pure SF6," National Institute of Standards and Technology, Washington, DC, USA, Tech. Rep. 1425, 1997, pp. 1-44.

[18] M. N. Ngoc, A. Denat, N. Bonifaci, O. Lesaint, and M. Hassanzadeh, "Impulse partial discharges and breakdown of CF3I in highly non-uniform field," in Proc. 18th Int. Conf. Gas Discharges Appl., 2010, Greifswald, Germany, pp. 330-333.

[19] E. Kuffel, W. S. Zaengl, and J. Kuffel, High Voltage EngineeringFundamentals, 2nd ed. Oxford, U.K.: Newnes, 2000.

[20] Y. Kawaguchi, K. Sakata, and S. Menju, "Effect of a grounded cylinder enclosure on the breakdown gradient of rod gaps in SF6," IEEE Trans. Power App. Syst., vol. PAS-90, no. 3, pp. 1079-1085, May 1971

[21] B. S. Manjunath, K. Dwarakanath, K. S. Arunachala Sastry, and K. N. Ravi, "Uniform field breakdown in SF6 gas at high pressures under lightning and switching surge voltages," in Proc. IEEE Conf. Elect. Insul. Dielect. Phenom., 1988, Ottawa, ON, Canada, pp. 329-333.

[22] P. R. Howard, "Process contributing to the breakdown of electronegative gases in uniform and non-uniform electric fields," Proc. IEE Part A, Power Eng., vol. 104, no. 14, pp. 139-142, Apr. 1957.

[23] S. Menju, H. Aoyagi, K. Takahashi, and H. Qhno, "Dielectric breakdown of high pressure SF6 in sphere and coaxial cylinder gaps," IEEE Trans. Power App. Syst., vol. PAS-93, no. 5, pp. 1706-1712, Oct. 1974.

[24] H. Koch, "Basic information on gas insulated transmission lines (GIL)," in Proc. Power Energy Soc. Gen. Meeting, Pittsburgh, PA, USA, 2008, pp. 1-4.

[25] "Compressed gas insulated transmission bus systems-Proven solutions for power transmission," AZZ CGIT Tech. Brouchure 001, Westborough, MA, USA, 2004

[26] L. Chen, P. Widger, M. S. Kamarudin, H. Griffiths, and A. Haddad, "Potential of CF3I gas mixture as an insulation medium in gas-insulated equipment," in Proc. IEEE Conf. Elect. Insul. Dielect. Phenom., 2015, Ann Arbor, MI, USA, pp. 868-871.

[27] L. Chen, "Investigation on the feasibility of trifluoroiodomethane (CF3I) for application in gas-insulated lines," Ph.D. dissertation, Adv. High Voltage Eng. Res. Centre, Cardiff University, Cardiff, U.K., 2015.

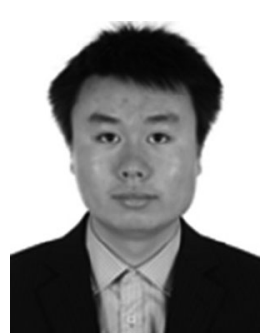

Lujia Chen (M'13) received the B.Eng. (Hons.) degree in electrical and electronic engineering and the $\mathrm{Ph} . \mathrm{D}$. degree in high voltage engineering both from Cardiff University, Cardiff, U.K., in 2012 and 2015, respectively.

$\mathrm{He}$ is currently working toward the characterization of $\mathrm{CF}_{3} \mathrm{I}$ in a gas-insulated line demonstrator. His research interests include the feasibility of replacing $\mathrm{SF}_{6}$ with an environmental friendly insulation medium in gas-insulated equipment.

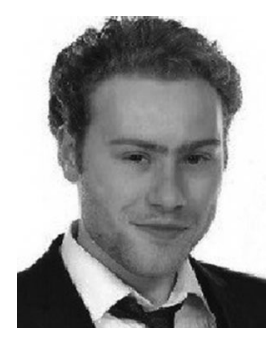

Phillip Widger received the B.Eng. and Ph.D. degrees in electrical and electronic engineering from Cardiff University, Cardiff, U.K., in 2014 and 2010, respectively. Between 2010 and 2014, he worked toward the Ph.D. degree in the Advanced High Voltage Engineering Research Centre, Cardiff University.

Since then, he has been working as a Research Associate at Cardiff University. His research interests include alternatives gases to $\mathrm{SF}_{6}$, specializing in gas mixtures of $\mathrm{CF}_{3} \mathrm{I}$, for use in distribution and transmission networks.

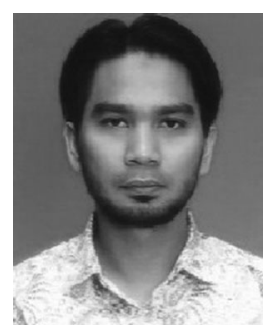

Mohammad Saufi Kamarudin received the B.Eng. and M.Eng. degrees in electrical engineering (power) from the Universiti Teknologi Malaysia, Johor, Malaysia, in 2003 and 2005, respectively, and the $\mathrm{Ph} . \mathrm{D}$. degree in high voltage engineering from Cardiff University, Cardiff, U.K., in 2014.

$\mathrm{He}$ is currently a Senior Lecturer in the Faculty of Electrical and Electronic Engineering, Universiti of Tun Hussein Onn Malaysia, Johor, Malaysia. His research interests include gas discharges, high voltage surge arresters and dielectrics, and electrical insula-

tion systems

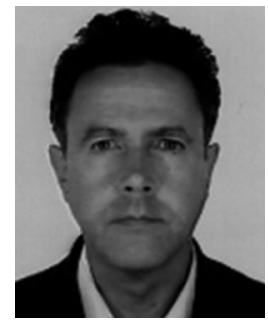

Huw Griffiths (M'13) received the B.Sc. degree in electrical and electronic engineering from the Polytechnic of Wales, Wales, U.K., and the Ph.D. degree in electrical engineering from Cardiff University, Cardiff, U.K.

Between 1983 and 1990, he worked at the South Wales Electricity Board and the Central Electricity Generating Board in distribution and transmission system design. In 1990, he was appointed to the lecturing staff at Cardiff University. He is currently a Professor in the High Voltage Group and at the Petroleum Institute, Abu Dhabi, UAE, where he is currently based. His research interests include earthing systems and high voltage insulation.

Dr. Griffiths is a Chartered Engineer and a member of the IET. He is also a member of a number of BSI, CENELEC, IEC, CIGRE, and CIRED working groups and committees.

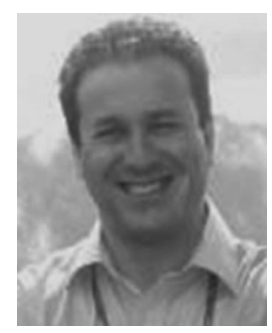

A. Haddad (M'13) received the Ingénieur d'État degree in electrical engineering from the Ecole Nationale Polytechnique of Algiers, in 1985 and the $\mathrm{Ph} . \mathrm{D}$. degree in high voltage engineering from Cardiff University, Cardiff, U.K., in 1990.

He is currently a Professor of Electrical Engineering with Cardiff University, Cardiff, U.K., responsible for research in high-voltage engineering. $\mathrm{He}$ has authored an IET- Power Series Book entitled $A d$ vances in High-Voltage Engineering. His research interests include overvoltage protection, insulation systems, insulation coordination, and earthing of electrical energy systems.

Prof. Haddad is a member of several CIGRE working groups and a member of standard committees IEC TC37 MT4 and MT10 and IEC ACTAD. 